\title{
Synthesis and Characterization of Bis(4-methylbenzylammonium) Tetrachloridocadmate(II)
}

\author{
R. Kefi, ${ }^{1}$ M. Zeller, ${ }^{2}$ F. Lefebvre, ${ }^{3}$ and C. Ben Nasr ${ }^{1}$ \\ ${ }^{1}$ Laboratoire de Chimie des Matériaux, Faculté des Sciences de Bizerte, Zarzouna 7021, Tunisia \\ ${ }^{2}$ Department of Chemistry, Youngstown State University, One University Plaza, Youngstown, OH 44555-3663, USA \\ ${ }^{3}$ Laboratoire de Chimie Organometallique de Surface (LCOMS), Ecole Supérieure de Chimie Physique Electronique, \\ 69622 Villeurbanne Cedex, France
}

Correspondence should be addressed to C. Ben Nasr, cherif.bennasr@fsb.rnu.tn

Received 11 November 2011; Accepted 13 December 2011

Academic Editor: Alexander Steiner

Copyright ( $) 2011$ R. Kefi et al. This is an open access article distributed under the Creative Commons Attribution License, which permits unrestricted use, distribution, and reproduction in any medium, provided the original work is properly cited.

The crystal structure of the new inorganic-organic hybrid compound $\left[4-\mathrm{CH}_{3} \mathrm{C}_{6} \mathrm{H}_{4} \mathrm{CH}_{2} \mathrm{NH}_{3}\right]_{2}\left[\mathrm{CdCl}_{4}\right]$ has been determined by single crystal X-ray diffraction. The compound crystallizes in the orthorhombic space group Pnma with lattice parameters $a=$ $10.721(2), b=33.986(6), c=5.326(1) \AA, \beta=97.222(1)^{\circ}, V=1940.8(7) \AA^{3}$, and $Z=4$. The framework of the title compound is built upon layers parallel to (010) made up from corner-sharing $\mathrm{CdCl}_{6}$ octahedra. 4-Methylbenzylammonium cations are situated between the layers and connect them via an $\mathrm{N}-\mathrm{H} \cdots \mathrm{Cl}$ hydrogen bonding network. The Cd atom is located on an inversion centre, and the coordination environment is described as distorted octahedral. Solid state ${ }^{13} \mathrm{C}$ CP-MAS NMR spectroscopy is in agreement with the X-ray structure. DFT calculations allow the attribution of the carbon peaks to the independent crystallographic sites. Thermal analysis and infrared spectroscopy were also used to characterize the complex.

\section{Introduction}

In recent years, a great effort has been devoted to the selfassembly of organic and inorganic molecules in the solid state, because it allows to design new solids with specific properties, such as electronic, optical, thermal, and catalytic $[1,2]$. Among these materials, chlorocadmate compounds have been of special interest for their structural flexibility. Complexes with $\mathrm{Cd}(\mathrm{II})$ centers have been at the center of growing interest due to their variable frameworks, and their potential photoluminescent and nonlinear optical (NLO) properties $[3,4]$. They can occur as simple tetrahedral anions $\mathrm{CdX}_{4}^{2-}$ or form the backbone of chain polymers. This is due to the fact that the $\mathrm{Cd}^{2+}$ ion, being a d10 transition metal ion, exhibits a great variety of coordination numbers and geometries, depending on crystal packing and hydrogen bonding, as well as halide dimensions [5-10]. A wide variety of stoichiometries that belong to this class of compounds makes the crystal chemistry of chlorocadmates extremely diverse and complex. Common features of all these compounds are the invariable presence of octahedral $\left(\mathrm{CdCl}_{6}\right)$ units in the anhydrous species. A network of hydrogen bonding, involving organic cations, generally connects the inorganic anions together and stabilizes the whole crystal structure [11-14]. Therefore, the Cd(II) salt is suitable for the assembly of coordination frameworks.

As a part of our ongoing investigations in molecular salts containing metal-chlorido complexes $[15,16]$, we present here the crystal structure of one such compound, [4$\left.\mathrm{CH}_{3} \mathrm{C}_{6} \mathrm{H}_{4} \mathrm{CH}_{2} \mathrm{NH}_{3}\right]_{2}\left[\mathrm{CdCl}_{4}\right]$.

\section{Experimental}

2.1. Chemical Preparation. 4-Methybenzylamine $(2 \mathrm{mmol}$, $0.242 \mathrm{~g})$ and $\mathrm{CdCl}_{2}(1 \mathrm{mmol}, 0.183 \mathrm{~g})$ were dissolved in dilute $\mathrm{HCl}(10 \mathrm{~mL}, 1 \mathrm{M})$, and the resultant solution was slowly evaporated at room temperature. A crystal of the title compound, which remained stable under normal conditions of temperature and humidity, was isolated after several days and subjected to X-ray diffraction analysis (yield 56\%). Element analysis calculated: C 38.51, H 4.81, N 5.61\%; found: C 38.46, H 4.67, N 5.78\%. 
2.2. Investigation Techniques. The characterization of these salts was carried out using X-ray diffraction, solid state NMR spectroscopy, DFT calculations, infrared spectroscopy, and thermal analysis (differential thermal analysis, DTA, and thermal gravimetric analysis, TGA).

2.2.1. X-Ray Diffraction. A single crystal was carefully selected under a microscope in order to perform its structural analysis by X-ray diffraction. The intensity data were collected on a Bruker AXS SMART APEX CCD diffractometer using the omega scan technique with $\operatorname{MoK} \alpha$ radiation $(\lambda$ $=0.7107 \AA$ ). The structure was solved with direct methods using SHELXS-97 [17] and refined with full-matrix leastsquares techniques using SHELXTL-6.14 [18]. The drawings were made with Diamond [19]. Crystal data and experimental parameters used for the intensity data collection are summarized in Table 1.

Crystals of the title compound were also analyzed at lower temperature $(100 \mathrm{~K})$. At this temperature the diffraction patterns exhibit pronounced "streaks" of intensity between rows of well defined Bragg peaks, indicating modulation of the structure and disorder of molecular entities with repeating patterns that are not a multiple of the basic unit cell as defined by the main Bragg peaks. Integration of only the Bragg peaks under omission of the streaks confirmed this. The average structure thus obtained shows substantial disorder of some of the chlorine atoms, with ratios refining to an $82: 18$ ratio. It can be imagined that the positions of the $\mathrm{Cl}$ atoms in neighboring layers of $\mathrm{Cd}$ and $\mathrm{Cl}$ are in some way related, but not in a way that repeats itself within the dimensions given by the unit cells, thus causing the nonBragg like behavior at $100 \mathrm{~K}$. No attempts were made to completely analyze the non-Bragg low temperature phase of the compound.

2.2.2. NMR Spectroscopy. The ${ }^{13} \mathrm{C}$ NMR spectrum was recorded on a solid-state high-resolution Bruker DSX-300 spectrometer operating at $75.49 \mathrm{MHz}$ with a classical $4 \mathrm{~mm}$ probehead allowing spinning rates up to $10 \mathrm{kHz}$. The chemical shifts are given relative to tetramethylsilane (external reference, precision $0.5 \mathrm{ppm}$ ). The spectrum was recorded by use of cross-polarization (CP) from protons (contact time $5 \mathrm{~ms}$ ) and MAS. Before recording the spectrum, it was checked that there was a sufficient delay between the scans allowing a full relaxation of the protons. DFT calculations were undertaken in order to assign the NMR resonances to the different nonequivalent $\mathrm{C}$ atoms of the unit cell. These calculations were made at the B3LYP/6-31+G* level using the GAUSSIAN98 program [20].

2.2.3. IR Spectroscopy. The spectrum was recorded in the range $4000-400 \mathrm{~cm}^{-1}$ with a "Perkin-Elmer FTIR" spectrophotometer 1000 using a sample dispersed in spectroscopically pure $\mathrm{KBr}$ pressed into a pellet.

2.2.4. Thermal Analysis. Thermal analysis was performed using the "multimodule 92 Setaram" analyzer operated
TAвLe 1: Cristallographic data and refinement details of the title compound.

\begin{tabular}{|c|c|}
\hline $\mathrm{CdCl}_{4} \cdot\left(\mathrm{C}_{8} \mathrm{H}_{12} \mathrm{~N}\right)_{2}$ & $F(000)=1000.00$ \\
\hline$M_{r}=498.57$ & $D_{x}=1.706 \mathrm{Mg} \mathrm{m}^{-3}$ \\
\hline Orthorhombic, Pnma & Mo $K \alpha$ radiation, $\lambda=0.71073 \AA$ \\
\hline$a=10.721(2) \AA$ & $\begin{array}{l}\text { Cell parameters from } 670 \\
\text { reflections }\end{array}$ \\
\hline$b=33.986(6) \AA$ & $\theta=2.4-31.3^{\circ}$ \\
\hline$c=5.326(1) \AA$ & $\mu=1.68 \mathrm{~cm}^{-1}$ \\
\hline$\beta=97.222(1)^{\circ}$ & $T=289 \mathrm{~K}$ \\
\hline$V=1940.8(7) \AA^{3}$ & $\begin{array}{l}\text { Crystal size: } 0.009 \times 0.08 \times \\
0.06 \mathrm{~mm}\end{array}$ \\
\hline$Z=4$ & 2856 independent reflections \\
\hline$\varphi$ and $\omega$ scans & 2278 reflections with $I>2 \sigma(I)$ \\
\hline$T_{\min }=0.608, T_{\max }=0.746$ & $R_{\text {int }}=0.023$ \\
\hline Color: colourless & $\theta_{\max }=30.1^{\circ}, \theta_{\min }=3.6^{\circ}$ \\
\hline Goodness-of-fit on $F^{2}: 1.1$ & $-14<h<14$ \\
\hline 6959 measured reflections & $-44<k<46$ \\
\hline Refinement on $F^{2}$ & $-1<l<7$ \\
\hline$R\left[F^{2}>2 \sigma\left(F^{2}\right)\right]=0.041$ & $\begin{array}{l}w= \\
1 /\left[\sigma^{2}\left(F_{o}^{2}\right)+(0.062 P)^{2}+0.2678 P\right] \\
\text { where } P=\left(F_{o}^{2}+2 F_{c}^{2}\right) / 3\end{array}$ \\
\hline$w R\left(F^{2}\right)=0.093$ & $(\Delta / \sigma)_{\max }=0.001$ \\
\hline 11674 reflections & $\Delta \rho_{\max }=1.23 \mathrm{e} \AA^{-3}$ \\
\hline 111 parameters & $\Delta \rho_{\min }=-1.78 \mathrm{e} \AA^{-3}$ \\
\hline
\end{tabular}

between room temperature and $773 \mathrm{~K}$ with an average heating rate of $5 \mathrm{~K} \cdot \mathrm{min}^{-1}$.

\section{Results and Discussion}

3.1. X-Ray Diffraction Study. The main geometrical features of the different chemical entities of the organic-inorganic hybrid compound $\left[4-\mathrm{CH}_{3} \mathrm{C}_{6} \mathrm{H}_{4} \mathrm{CH}_{2} \mathrm{NH}_{3}\right]_{2}\left[\mathrm{CdCl}_{4}\right]$ are reported in Tables 2, 3, and 4 .

The asymmetric unit of the title compound (Figure 1) contains one 4-methylbenzylammonium and one half of a $\mathrm{CdCl}_{2}\left(\mathrm{Cl}_{1 / 2}\right)_{4}$ fragment. Packing of [4$\left.\mathrm{CH}_{3} \mathrm{C}_{6} \mathrm{H}_{4} \mathrm{CH}_{2} \mathrm{NH}_{3}\right]_{2}\left[\mathrm{CdCl}_{4}\right]$ viewed along the $b$-axis (Figure 2) shows a layer of corner sharing $\left[\mathrm{CdCl}_{6}\right]$ octahedra. The minimum Cd-Cd distance within a layer is $5.362(1)$ $\AA$. In the structure, three symmetry independent chlorine atoms are observed $(\mathrm{Cl} 1, \mathrm{Cl} 2$, and $\mathrm{Cl} 3)$, and only $\mathrm{Cl} 1$ and $\mathrm{Cl} 3$ form a bridge between two cadmium centers. In this way, the chlorine atoms form a distorted octahedron around each cadmium atom (Figure 3 ), giving the overall stoichiometry for the anions of $\left[\mathrm{CdCl}_{2}\left(\mathrm{Cl}_{1 / 2}\right)_{4}\right]^{2-}$. The $\mathrm{Cd}$ atom is located on an inversion centre. Table 2 shows that the symmetric bridging $\mathrm{Cd}-\mathrm{Cl}$ distances are long, varying between 2.663(1) and 2.709(1) $\AA$, while the terminal Cd-Cl distances are close to $2.502(1) \AA$, which is typical of six coordinated $\mathrm{Cd}$ (II) [18]. The $\mathrm{Cl}-\mathrm{Cd}-\mathrm{Cl}$ bond angles average exactly $90.0^{\circ}$ and range between $84.62(5)^{\circ}$ for $\mathrm{Cl} 3-\mathrm{Cd} 1-\mathrm{Cl} 1$ and 92.92 (3) for $\mathrm{Cl} 2-\mathrm{Cd} 1-\mathrm{Cl} 3$ (Table 3 ), again confirming the close to symmetric octahedral nature of the $\mathrm{CdCl}_{6}$ building units. 
TABLE 2: Selected bond lengths $(\AA)$ in $\left[4-\mathrm{CH}_{3} \mathrm{C}_{6} \mathrm{H}_{4} \mathrm{CH}_{2} \mathrm{NH}_{3}\right]_{2}\left[\mathrm{CdCl}_{4}\right]$.

\begin{tabular}{lccc}
\hline $\mathrm{Cd} 1-\mathrm{Cl} 2$ & $2.5020(11)$ & $\mathrm{C} 5-\mathrm{C} 8$ & $1.506(6)$ \\
$\mathrm{Cd} 1-\mathrm{Cl} 2^{\mathrm{i}}$ & $2.5020(11)$ & $\mathrm{C} 2-\mathrm{C} 3$ & $1.385(6)$ \\
$\mathrm{Cd} 1-\mathrm{Cl} 3$ & $2.6557(15)$ & $\mathrm{C} 1-\mathrm{H} 1 \mathrm{~A}$ & 0.9700 \\
$\mathrm{Cd} 1-\mathrm{Cl} 1$ & $2.6630(14)$ & $\mathrm{C} 1-\mathrm{H} 1 \mathrm{~B}$ & 0.9700 \\
$\mathrm{Cd} 1-\mathrm{Cl} 1^{\mathrm{ii}}$ & $\mathrm{C} 7-\mathrm{H} 7$ & 0.9300 \\
$\mathrm{Cd} 1-\mathrm{Cl} 3^{\mathrm{iii}}$ & $2.6676(14)$ & $\mathrm{C}-\mathrm{H} 8 \mathrm{~A}$ & 0.9600 \\
$\mathrm{Cl} 1-\mathrm{Cd} 1^{\mathrm{iv}}$ & $2.7089(15)$ & $\mathrm{C} 8-\mathrm{H} 8 \mathrm{~B}$ & 0.9600 \\
$\mathrm{Cl} 3-\mathrm{Cd} 1^{\mathrm{v}}$ & $2.6677(14)$ & $\mathrm{C} 8-\mathrm{H} 8 \mathrm{C}$ & 0.9600 \\
$\mathrm{C} 1-\mathrm{N} 1$ & $2.7089(15)$ & $\mathrm{N} 1-\mathrm{H} 1 \mathrm{C}$ & 0.8900 \\
$\mathrm{C} 1-\mathrm{C} 2$ & $1.440(6)$ & $\mathrm{N} 1-\mathrm{H} 1 \mathrm{D}$ & 0.8900 \\
$\mathrm{C} 3-\mathrm{C} 4$ & $1.507(6)$ & $\mathrm{N} 1-\mathrm{H} 1 \mathrm{E}$ & 0.8900 \\
$\mathrm{C} 4-\mathrm{C} 5$ & $1.380(6)$ & $\mathrm{C} 6-\mathrm{H} 6$ & 0.9300 \\
$\mathrm{C} 6-\mathrm{C} 7$ & $1.386(6)$ & $\mathrm{C} 3-\mathrm{H} 3$ & 0.9300 \\
$\mathrm{C} 2-\mathrm{C} 7$ & $1.378(6)$ & $\mathrm{C} 4-\mathrm{H} 4$ & 0.9300 \\
$\mathrm{C} 5-\mathrm{C} 60$ & $1.367(6)$ & & \\
\hline
\end{tabular}

Symmetry codes: (i) $x,-y+1 / 2, z$; (ii) $x, y, z-1$; (iii) $x-1 / 2, y,-z+1 / 2$; (iv) $x, y, z+1$; (v) $x+1 / 2, y,-z+1 / 2$.

TABLE 3: Selected bond angles $\left(^{\circ}\right)$ in $\left[4-\mathrm{CH}_{3} \mathrm{C}_{6} \mathrm{H}_{4} \mathrm{CH}_{2} \mathrm{NH}_{3}\right]_{2}\left[\mathrm{CdCl}_{4}\right]$.

\begin{tabular}{|c|c|c|c|}
\hline $\mathrm{Cl} 2-\mathrm{Cd} 1-\mathrm{Cl} 2^{\mathrm{i}}$ & $174.05(7)$ & C2-C7-C6 & $121.8(4)$ \\
\hline $\mathrm{Cl} 2-\mathrm{Cd} 1-\mathrm{Cl} 3$ & $92.92(3)$ & N1-C1-H1A & 109.0 \\
\hline $\mathrm{Cl} 2^{\mathrm{i}}-\mathrm{Cd} 1-\mathrm{Cl} 3$ & $92.92(3)$ & $\mathrm{C} 2-\mathrm{C} 1-\mathrm{H} 1 \mathrm{~A}$ & 109.0 \\
\hline $\mathrm{Cl} 2-\mathrm{Cd} 1-\mathrm{Cl} 1$ & $90.87(3)$ & N1-C1-H1B & 109.0 \\
\hline $\mathrm{Cl} 2^{\mathrm{i}}-\mathrm{Cd} 1-\mathrm{Cl} 1$ & $90.87(3)$ & $\mathrm{C} 2-\mathrm{C} 1-\mathrm{H} 1 \mathrm{~B}$ & 109.0 \\
\hline $\mathrm{Cl} 3-\mathrm{Cd} 1-\mathrm{Cl} 1$ & $84.62(5)$ & C5-C8-H8C & 109.5 \\
\hline $\mathrm{Cl} 2-\mathrm{Cd} 1-\mathrm{Cl} 1^{\mathrm{ii}}$ & $89.36(3)$ & C1-N1-H1C & 109.5 \\
\hline $\mathrm{Cl} 2^{\mathrm{i}}-\mathrm{Cd} 1-\mathrm{Cl} 1^{\mathrm{ii}}$ & $89.35(3)$ & C1-N1-H1D & 109.5 \\
\hline $\mathrm{Cl} 3-\mathrm{Cd} 1-\mathrm{Cl}^{\mathrm{ii}}$ & $90.92(5)$ & $\mathrm{C} 4-\mathrm{C} 3-\mathrm{H} 3$ & 119.6 \\
\hline $\mathrm{Cl} 1-\mathrm{Cd} 1-\mathrm{Cl} 1^{\mathrm{ii}}$ & $175.54(7)$ & $\mathrm{C} 2-\mathrm{C} 3-\mathrm{H} 3$ & 119.6 \\
\hline $\mathrm{Cl} 2-\mathrm{Cd} 1-\mathrm{Cl} 3^{\mathrm{iii}}$ & $87.12(3)$ & C3-C4-H4 & 119.5 \\
\hline $\mathrm{Cl} 2^{\mathrm{i}}-\mathrm{Cd} 1-\mathrm{Cl} 3^{\mathrm{iii}}$ & $87.12(3)$ & C5-C4-H4 & 119.5 \\
\hline $\mathrm{Cl} 3-\mathrm{Cd} 1-\mathrm{Cl}^{\mathrm{iii}}$ & $177.204(13)$ & C1-N1-H1E & 109.5 \\
\hline $\mathrm{Cl} 1-\mathrm{Cd} 1-\mathrm{Cl} 3^{\mathrm{iii}}$ & $92.58(5)$ & C7-C6-H6 & 119.8 \\
\hline $\mathrm{Cl} 1^{\mathrm{ii}}-\mathrm{Cd} 1-\mathrm{Cl} 3^{\mathrm{iii}}$ & $91.88(5)$ & C5-C6-H6 & 119.8 \\
\hline $\mathrm{Cd} 1-\mathrm{Cl} 1-\mathrm{Cd} 1^{\mathrm{iv}}$ & $175.54(7)$ & $\mathrm{C} 2-\mathrm{C} 7-\mathrm{H} 7$ & 119.1 \\
\hline $\mathrm{Cd} 1-\mathrm{Cl} 3-\mathrm{Cd} 1^{\mathrm{v}}$ & $176.50(7)$ & C6-C7-H7 & 119.1 \\
\hline $\mathrm{N} 1-\mathrm{C} 1-\mathrm{C} 2$ & $113.1(4)$ & C5-C8-H8A & 109.5 \\
\hline C7-C2-C3 & $118.1(4)$ & C5-C8-H8B & 109.5 \\
\hline $\mathrm{C} 7-\mathrm{C} 2-\mathrm{C} 1$ & $121.0(4)$ & $\mathrm{H} 8 \mathrm{~A}-\mathrm{C} 8-\mathrm{H} 8 \mathrm{C}$ & 109.5 \\
\hline $\mathrm{C} 3-\mathrm{C} 2-\mathrm{C} 1$ & $120.9(4)$ & $\mathrm{H} 8 \mathrm{~A}-\mathrm{C} 8-\mathrm{H} 8 \mathrm{~B}$ & 109.5 \\
\hline $\mathrm{C} 4-\mathrm{C} 3-\mathrm{C} 2$ & $120.8(4)$ & $\mathrm{H} 1 \mathrm{~A}-\mathrm{C} 1-\mathrm{H} 1 \mathrm{~B}$ & 107.8 \\
\hline C3-C4-C5 & $121.0(4)$ & H1C-N1-H1E & 109.5 \\
\hline C4-C5-C6 & $117.9(4)$ & H1D-N1-H1E & 109.5 \\
\hline C4-C5-C8 & $121.2(4)$ & $\mathrm{H} 8 \mathrm{~B}-\mathrm{C} 8-\mathrm{H} 8 \mathrm{C}$ & 109.5 \\
\hline C6-C5-C8 & $120.9(4)$ & H1C-N1-H1D & 109.5 \\
\hline C7-C6-C5 & $120.5(4)$ & & \\
\hline
\end{tabular}

Symmetry codes: (i) $x,-y+1 / 2, z$; (ii) $x, y, z-1$; (iii) $x-1 / 2, y,-z+1 / 2$; (iv) $x, y, z+1$; (v) $x+1 / 2, y,-z+1 / 2$. 
TABle 4: Hydrogen-bond geometry $\left(\AA,^{\circ}\right)$ in [4$\left.\mathrm{CH}_{3} \mathrm{C}_{6} \mathrm{H}_{4} \mathrm{CH}_{2} \mathrm{NH}_{3}\right]_{2}\left[\mathrm{CdCl}_{4}\right]$.

\begin{tabular}{|c|c|c|c|c|}
\hline $\mathrm{D}-\mathrm{H} \cdots \mathrm{A}$ & $\mathrm{D}-\mathrm{H}$ & $\mathrm{H} \cdots \mathrm{A}$ & $\mathrm{D} \cdots \mathrm{A}$ & $\mathrm{D}-\mathrm{H} \cdots \mathrm{A}$ \\
\hline $\mathrm{N} 1-\mathrm{H} 1 C \cdots \mathrm{Cl}$ & 0.89 & 2.76 & $3.418(4)$ & 131 \\
\hline $\mathrm{N} 1-\mathrm{H} 1 D \cdots \mathrm{Cl}^{\mathrm{vi}}$ & 0.89 & 2.70 & $3.474(4)$ & 147 \\
\hline $\mathrm{N} 1-\mathrm{H} 1 D \cdots \mathrm{Cl}^{\mathrm{vi}}$ & 0.89 & 2.82 & $3.479(4)$ & 132 \\
\hline $\mathrm{N} 1-\mathrm{H} 1 E \cdots \mathrm{Cl} 3^{\mathrm{iii}}$ & 0.89 & 2.67 & $3.399(4)$ & 140 \\
\hline
\end{tabular}

Symmetry codes: (iii) $x-1 / 2, y,-z+1 / 2$; (vi) $x-1 / 2, y,-z+3 / 2$.
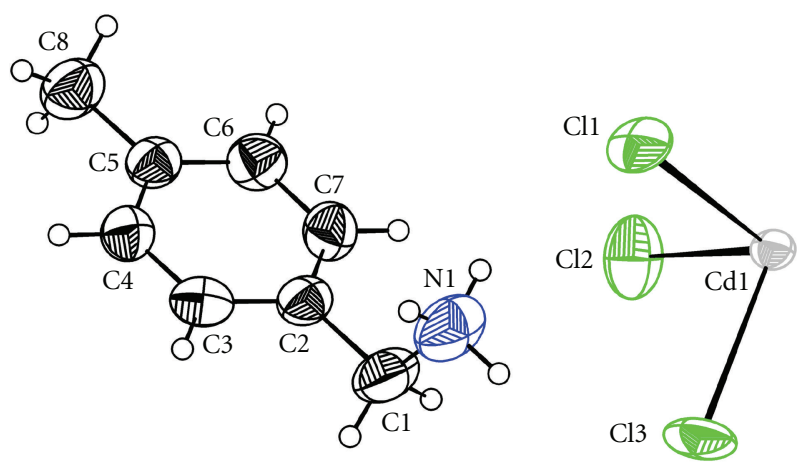

Figure 1: Asymmetric unit of [4- $\left.\mathrm{CH}_{3} \mathrm{C}_{6} \mathrm{H}_{4} \mathrm{CH}_{2} \mathrm{NH}_{3}\right]_{2}\left[\mathrm{CdCl}_{4}\right]$ with atom labels and $50 \%$ probability displacement ellipsoids for non- $\mathrm{H}$ atoms.

In this structure, the 4-methylbenzylammonium cationic group compensates the negative charge of a half $\left[\mathrm{CdCl}_{2}\left(\mathrm{Cl}_{1 / 2}\right)_{4}\right]^{2-}$ anion leading to neutrality for the structure as a whole. Figure 4 shows $\mathrm{CdCl}_{6}$ octahedra and the 4-methylbenzylammonium cations connected via hydrogen bonds $\mathrm{N} 1-\mathrm{H} 1 \mathrm{C} \cdot \mathrm{Cl}$, $\mathrm{N} 1-\mathrm{H} 1 \mathrm{D} \cdot \mathrm{Cl} \mathrm{Cl}^{\text {vi }}$, $\mathrm{N} 1-\mathrm{H} 1 \mathrm{D} \cdot \mathrm{Cl} 1^{\mathrm{vi}}$, and $\mathrm{N} 1-\mathrm{H} 1 \mathrm{E} \cdot \mathrm{Cl} 3^{\mathrm{iii}}$, one of which is bifurcated N1-H1D $\cdots\left(\mathrm{Cl}^{\mathrm{vi}}, \mathrm{Cl}^{\mathrm{vi}}\right)$ (symmetry codes in Table 4). Only the bridging chlorine atoms $\mathrm{Cl} 1$ and $\mathrm{Cl} 3$ of the $\mathrm{CdCl}_{6}$ octahedron participate in hydrogen bonding, while all hydrogen atoms that are attached to N1 are involved in hydrogen bondings. No $\pi-\pi$ stacking interactions between neighboring aromatic rings or $\mathrm{C}-\mathrm{H} \cdots \pi$ interactions towards them are observed. The interlayer space is large enough to allow for only minimal distortions of the cation. The angles and atom distances of the cation have their usual values as reported for the related compound with the same cation, bis(4-methylbenzylammonium) tetrachlorozincate [21]. It is worth noting that as cadmium is found in the second period of the transition metals, it has more variable coordination numbers and geometries than zinc. This explains the difference of the architectures between the cadmium and zinc salts. Indeed, for the title compound, the $\mathrm{CdCl}_{6}$ octahedra are sharing their common vertex of chlorine, while, in the $\mathrm{Zn}$ (II) salt [21], the $\mathrm{ZnCl}_{4}$ tetrahedra are linked by hydrogen bonds.

3.1.1. NMR Spectroscopy. The ${ }^{13} \mathrm{C}$ CP-MAS NMR spectrum of the title compound is shown on Figure 5. It displays two well-defined peaks in the resonance region of the aliphatic carbon atoms, at 22.2 and $44.3 \mathrm{ppm}$, showing that the

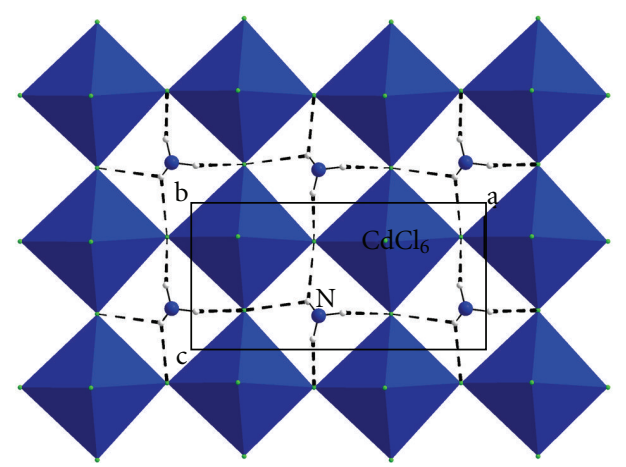

Figure 2: Projection of [4- $\left.\mathrm{CH}_{3} \mathrm{C}_{6} \mathrm{H}_{4} \mathrm{CH}_{2} \mathrm{NH}_{3}\right]_{2}\left[\mathrm{CdCl}_{4}\right]$ structure in the plane $(\mathrm{a}, \mathrm{c})$. The dotted lines indicate hydrogen bonds. A polyhedral representation is given for $\left[\mathrm{CdCl}_{6}\right]$.

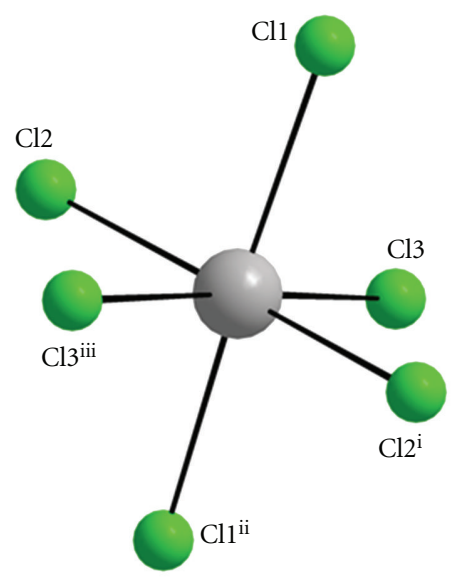

FIgURE 3: Coordination geometry of $\mathrm{Cd}(\mathrm{II})$ ions in [4$\left.\mathrm{CH}_{3} \mathrm{C}_{6} \mathrm{H}_{4} \mathrm{CH}_{2} \mathrm{NH}_{3}\right]_{2}\left[\mathrm{CdCl}_{4}\right]$. Symmetry codes: (i) $x,-y+1 / 2, z$; (ii) $x, y, z-1$; (iii) $x-1 / 2, y,-z+1 / 2$.

asymmetric unit cell should contain only one organic molecule, which is in good agreement with the X-ray results (Figure 1). Theoretical calculations were then undertaken in order to assign the NMR resonances to the different crystallographically inequivalent carbon atoms of the unit cell. These calculations were made at the B3LYP/6-31+G* level. The different atoms were labeled as depicted below:<smiles>Cc1[c]ccc(CN)c1</smiles>

Three different calculations were made on the organic cation, and, in all cases, the theoretical chemical shifts were subtracted from those of the reference (tetramethylsilane) calculated at the same level of theory:

(1) calculation of the NMR chemical shifts (with the GIAO method) by taking the positions of atoms obtained by X-ray diffraction; 
TABLE 5: Calculated and experimental ${ }^{13} \mathrm{C}$ chemical shifts in the studied compound.

\begin{tabular}{lcccc}
\hline Atom & No optimization & Optimization of all atoms & Optimization of protons & Experimental \\
\hline C1 & 122.8 & 134.9 & 128.9 & 122.9 \\
C2 & 121.2 & 126.7 & 131.9 & 128.3 \\
C3 & 125.8 & 134.9 & 137.7 & 130.0 \\
C4 & 132 & 140.5 & 155.7 & 131.8 \\
C5 & 156.9 & 159.8 & 137.5 & 137.4 \\
C6 & 131.7 & 140.5 & 45.2 & 131.8 \\
C7 & 27.4 & 59.9 & 23.8 & 44.3 \\
C9 & 0.8 & 24 & & 22.2 \\
\hline
\end{tabular}



Figure 4: Projection of [4- $\left.\mathrm{CH}_{3} \mathrm{C}_{6} \mathrm{H}_{4} \mathrm{CH}_{2} \mathrm{NH}_{3}\right]_{2}\left[\mathrm{CdCl}_{4}\right]$ structure along the $c$-axis. The dotted lines indicate hydrogen bonds. A polyhedral representation is given for $\left[\mathrm{CdCl}_{6}\right]$.

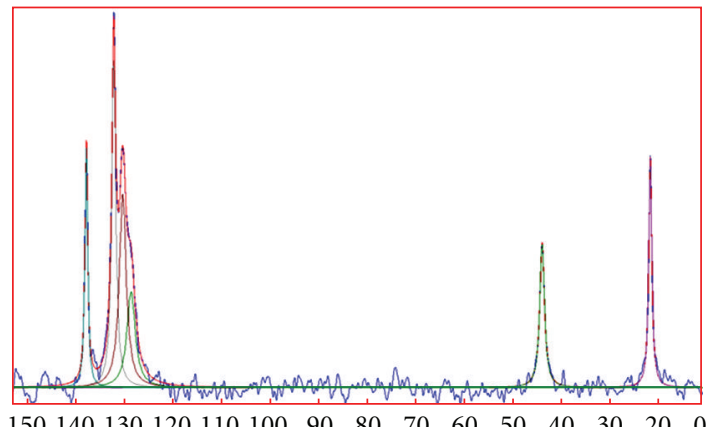

FIGURE 5: Experimental and simulated ${ }^{13} \mathrm{C}$ CP-MAS NMR spectra of the studied compound.

(2) optimization of the positions of the protons in the above molecule and calculation of the NMR chemical shifts in this semioptimized geometry. Indeed, Xray diffraction leads always to underestimated $\mathrm{X}-\mathrm{H}$ bond lengths, due to the fact that it is sensitive to the electronic cloud and does not see the nuclei;
(3) full optimization of all atoms and calculation of NMR chemical shifts. This calculation, compared to the above one, will give indications on the steric hindrance around the organic cation and on the positions where it is the strongest.

The results are listed in Table 5 which shows that there is a good agreement between the experimental and theoretical values calculated after optimization of the position of the protons, allowing unambiguously the attribution of the different NMR signals to the carbon atoms of the structure.

3.1.2. IR Spectroscopy. The IR spectrum of crystalline [4$\left.\mathrm{CH}_{3} \mathrm{C}_{6} \mathrm{H}_{4} \mathrm{CH}_{2} \mathrm{NH}_{3}\right]_{2}\left[\mathrm{CdCl}_{4}\right]$ is shown in Figure 6. The most representative and characteristic vibrational modes of this compound can be compared to those of similar complexes [22]. Some aspects of the performed assignments are briefly commented as follows.

(i) In the high-frequency region, the broad band between 3600 and $2500 \mathrm{~cm}^{-1}$ corresponds to the valence vibrations of $\mathrm{CH}$ and $\mathrm{NH}$ groups [23].

(ii) The observed bands in the $1620-1200 \mathrm{~cm}^{-1}$ region can be attributed to the bending vibrations of $\mathrm{NH}$ groups and to the valence vibrations of $\mathrm{C}=\mathrm{C}$ and $\mathrm{CN}$ groups [24].

(iii) The bands between 1000 and $700 \mathrm{~cm}^{-1}$ are assigned to out of plane bending modes $\gamma\left(\mathrm{C}_{\text {ary }}-\mathrm{H}\right)$ and $\gamma\left(\mathrm{C}_{\text {ary }}-\mathrm{C}\right)$ [25].

3.1.3. Thermal Analysis. Simultaneous TGA-DTA curves of the bis(4-methylbenzylammonium) tetrachlorido-cadmate(II) are given in Figure 7. The DTA curve shows that this compound undergoes a series of endothermic transformations in a wide temperature range (560-773 K). The most important one appears at about $565 \mathrm{~K}$. It corresponds to the melting point, which is in good agreement with the result obtained by the capillarity tube method. The important weight loss observed in this temperature region is attributed to the degradation of the organic entity. A black residue is obtained at the end of the experiment.

Additional Material. Crystallographic data for the title compound have been deposited at the Cambridge Crystallographic Data Center as supplementary publication (CCDC 


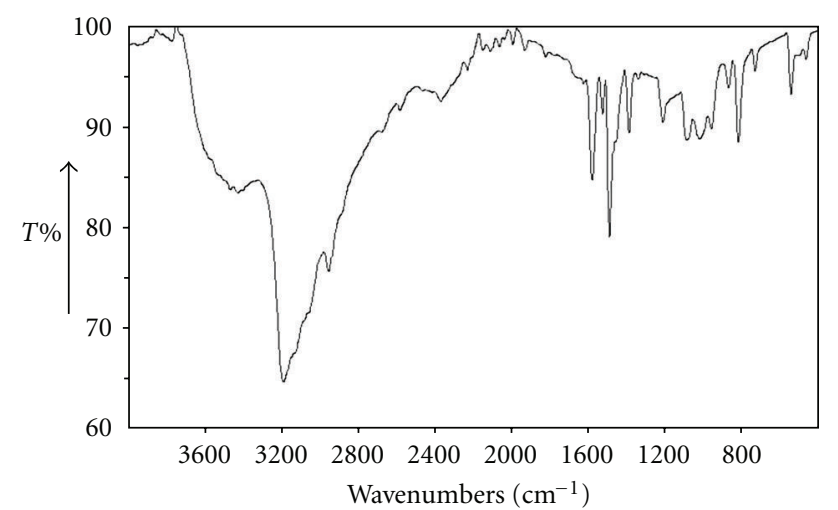

FIGURE 6: IR absorption spectrum of [4$\left.\mathrm{CH}_{3} \mathrm{C}_{6} \mathrm{H}_{4} \mathrm{CH}_{2} \mathrm{NH}_{3}\right]_{2}\left[\mathrm{CdCl}_{4}\right]$.

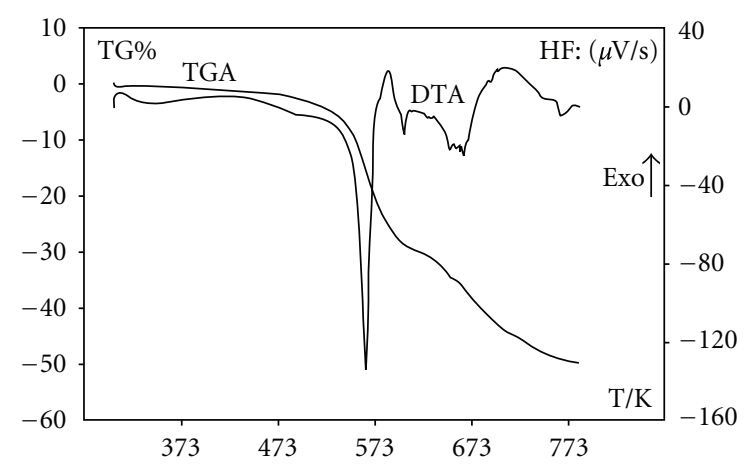

Figure 7: DTA and TGA curves of $\left[4-\mathrm{CH}_{3} \mathrm{C}_{6} \mathrm{H}_{4} \mathrm{CH}_{2} \mathrm{NH}_{3}\right]_{2}\left[\mathrm{CdCl}_{4}\right]$ at rising temperature.

852580). These data can be obtained free of charge at http://www.ccdc.cam.ac.uk/conts/retrieving.html (or from the Cambridge Crystallographic Data Center, 12, Union Road, Cambridge CB2 1EZ, UK; fax: +44 1223/336 033; mailto: deposit@ccdc.cam.ac.uk).

\section{Summary}

The title compound was prepared as single crystals at room temperature and characterized by physicochemical methods. On the structural level, the atomic arrangement of this material consists of a network of $\left[\mathrm{CdCl}_{2}\left(\mathrm{Cl}_{1 / 2}\right)_{4}\right]^{2-}$ anions and 4-methylbenzylammonium cations connected by $\mathrm{N}-\mathrm{H} \cdots \mathrm{Cl}$ hydrogen bonding interactions. The number of ${ }^{13} \mathrm{C}$ CP-MAS-NMR components is in full agreement with the ones of crystallographically independent sites. Upon heating, this salt melts and the organic entities degrade.

\section{References}

[1] N. Kimizuka and T. Kunitake, "Organic two-dimensional templates for the fabrication of inorganic nanostructures: organic/inorganic superlattices," Advanced Materials, vol. 8, no. 1, pp. 89-91, 1996.
[2] D. B. Mitzi, K. Chondroudis, and C. R. Kagan, "Organicinorganic electronics," IBM Journal of Research and Development, vol. 45, no. 1, pp. 29-45, 2001.

[3] R. Wang, M. Hong, J. Luo, R. Cao, Q. Shi, and J. Weng, "Syntheses and crystal structures of five cadmium(II) complexes derived from 4-aminobenzoic acid," European Journal of Inorganic Chemistry, no. 11, pp. 2904-2912, 2002.

[4] H. Fleischer, "Structural chemistry of complexes of $(n-1) \mathrm{d}^{10}$ $n s^{m} \mathrm{~m}$ metal ions with $\beta$-N-donor substituted thiolate ligands $(m=0,2)$," Coordination Chemistry Reviews, vol. 249, no. 7-8, pp. 799-827, 2005.

[5] L. J. Barbour, L. R. MacGillivray, and J. L. Atwood, "Structural consequences of $\mathrm{M}-\mathrm{Cl} \cdots \mathrm{H}-\mathrm{N}$ hydrogen bonds in substituted pyridinium salts of the cobalt(II)tetrachloride anion isolated from liquid clathrate media," Supramolecular Chemistry, vol. 7, no. 2, pp. 167-169, 1996.

[6] K. Müller-Dethlefs and P. Hobza, "Noncovalent interactions: a challenge for experiment and theory," Chemical Reviews, vol. 100, no. 1, pp. 143-167, 2000.

[7] F. H. Allen, V. J. Hoy, J. A. K. Howard et al., "Crystal engineering and correspondence between molecular and crystal structures. Are 2- and 3-aminophenols anomalous?" Journal of the American Chemical Society, vol. 119, no. 15, pp. 3477-3480, 1997.

[8] G. Aullón, D. Bellamy, L. Brammer, E. A. Bruton, and A. G. Orpen, "Metal-bound chlorine often accepts hydrogen bonds," Chemical Communications, no. 6, pp. 653-654, 1998.

[9] G. R. Lewis and A. G. Orpen, "A metal-containing synthon for crystal engineering: synthesis of the hydrogen bond ribbon polymer $\left[4,4^{\prime}-\mathrm{H}_{2}\right.$ bipy] $\left[\mathrm{MCl}_{4}\right](\mathrm{M}=\mathrm{Pd}, \mathrm{Pt}), "$ Chemical Communications, no. 17, pp. 1873-1874, 1998.

[10] B. Dolling, A. L. Gillon, A. G. Orpen, J. Starbuck, and X. M. Wang, "Homologous families of chloride-rich 4,4'-bipyridinium salt structures," Chemical Communications, no. 6, pp. 567-568, 2001.

[11] L. P. Battaglia, A. Bonamartini Corradi, G. Pelosi et al., "Synthesis and characterization of layered chlorocadmates(II) with perovskite-like structures," Chemistry of Materials, vol. 4, no. 4, pp. 813-818, 1992.

[12] J. T. Veal and D. J. Hodgson, "The crystal and molecular structure of tris(ethylenediamine)cobalt(III) hexachlorocadmate(II) dichloride dihydrate, $\left[\mathrm{Co}\left(\mathrm{N}_{2} \mathrm{C}_{2} \mathrm{H}_{8}\right)_{3}\right]_{2}\left[\mathrm{CdCl}_{6}\right] \mathrm{Cl}_{2}$. $2 \mathrm{H}_{2} \mathrm{O}$," Inorganic Chemistry, vol. 11, no. 3, pp. 597-600, 1972.

[13] A. B. Corradi, M. R. Cramarossa, and M. Saladini, "Design, synthesis, structural and thermal characterisation of polymeric chlorocadmate(II) compounds with one-dimensional inorganic chain structures," Inorganica Chimica Acta, vol. 257, no. 1, pp. 19-26, 1997.

[14] A. B. Corradi, A. M. Ferrari, and G. C. Pellacani, "Organicinorganic composite materials: structural archetypes of linear polymeric chlorocadmates (II)," Inorganica Chimica Acta, vol. 272, no. 1-2, pp. 252-260, 1998.

[15] M. E. Glaoui, E. Jeanneau, F. Lefebvre, and C. B. Nasr, "Synthesis and physicochemical studies of two new compounds $\mathrm{C}_{7} \mathrm{H}_{18} \mathrm{~N}_{2} \mathrm{O} \mathrm{TCl}_{4}(\mathrm{~T}=\mathrm{Cd}, \mathrm{Cu})$," Canadian Journal of Analytical Sciences and Spectroscopy, vol. 54, no. 2, pp. 70-82, 2009.

[16] M. E. Glaoui, R. Kefi, E. Jeanneau, F. Lefebvre, and C. B. Nasr, "Structural, spectroscopic and thermal investigations of a new bis(5-chloro-2,4-dimethoxyanilinium) tetrachloridocadmate trihydrate," Canadian Journal of Analytical Sciences and Spectroscopy, vol. 54, no. 1, pp. 1-10, 2009.

[17] G. M. Sheldrick, SHELXS-97, A Program for Automatic Solution of Crystal Structure, University of Göttingen, Göttingen, Germany, 1997. 
[18] Bruker Advanced X-ray Solutions, SHELXTL (Version 6.14), Bruker AXS Inc., Madison, Wis, USA, 2003.

[19] K. Brandenburg, Diamond Version 2.0 Impact, GbR, Bonn, Germany, 1998.

[20] M. J. Frisch et al., GAUSSIAN98, Gaussian Inc., Pittsburgh, Pa, USA, 1998.

[21] R. Kefi, E. Jeanneau, F. Lefebvre, and C. Ben Nasr, "Bis(4methylbenzylammonium) tetrachloridozincate: a new noncentrosymmetric structure characterized by 13C CP-MAS NMR spectroscopy," Acta Crystallographica, vol. C67, pp. m126-m129, 2011.

[22] I. B. Gharbia, A. Oueslati, C. B. Nasr, and F. Lefebvre, "Crystal structure and spectroscopic studies of 2-amino-3methylpyridinium tetrachlorozincate monohydrate, [2-NH2$\left.3-\mathrm{CH}_{3} \mathrm{C}_{5} \mathrm{H}_{3} \mathrm{NH}\right]_{2} \mathrm{ZnCl}_{4} \cdot \mathrm{H}_{2} \mathrm{O}$," Canadian Journal of Analytical Sciences and Spectroscopy, vol. 52, no. 1, pp. 32-45, 2007.

[23] A. Oueslati, A. Rayes, C. Ben Nasr, and F. Lefebvre, "Synthesis and characterization of 2-amino-3-methylpyridinium dihydrogenomonoarsenate," Materials Research Bulletin, vol. 40, no. 10, pp. 1680-1689, 2005.

[24] J. Oueslati, A. Oueslati, F. Lefebvre, M. Rzaïgui M, and C. Ben Nasr, "Structural and Spectroscopic Studies of 3,5-diamino4H-1,2,4-triazol-1-ium dihydrogenmonophosphate," Canadian Journal of Analytical Sciences and Spectroscopy, vol. 53, p. 36, 2007.

[25] R. Kefi, S. Abid, C. B. Nasr, and M. Rzaigui, "Synthesis and characterization of a new monophosphate (5-Cl-2,4$\left.\left(\mathrm{OCH}_{3}\right)_{2} \mathrm{C}_{6} \mathrm{H}_{2} \mathrm{NH}_{3}\right) \mathrm{H}_{2} \mathrm{PO}_{4}$," Materials Research Bulletin, vol. 42, no. 3, pp. 404-412, 2007. 


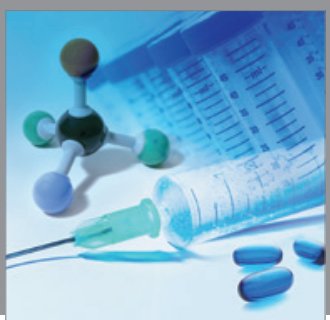

International Journal of

Medicinal Chemistry



Carbohydrate Chemistry

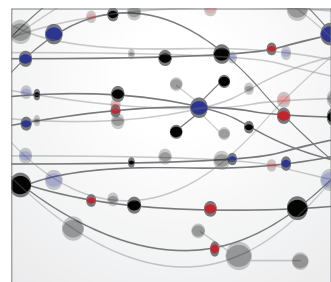

The Scientific World Journal
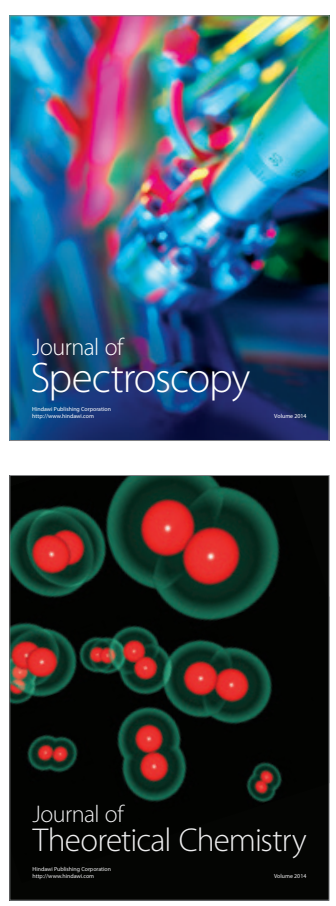
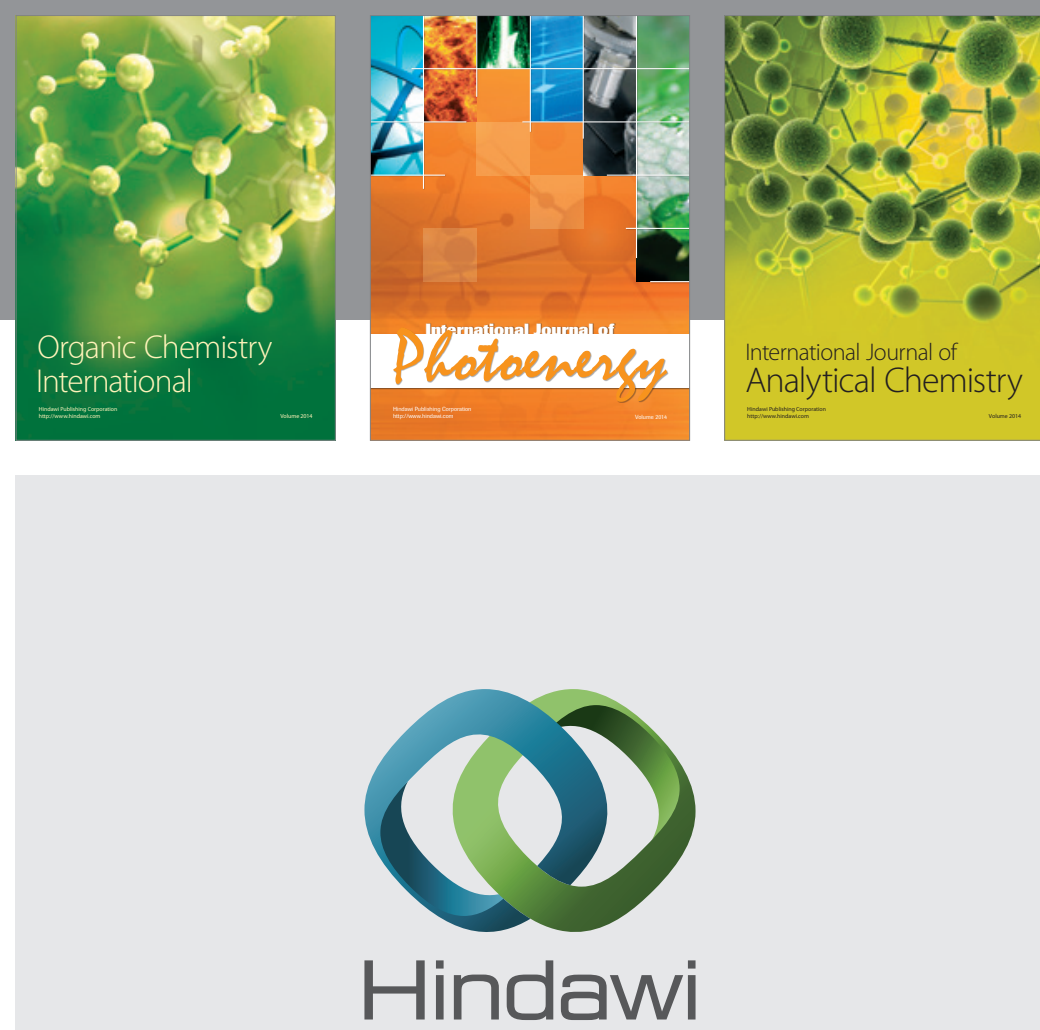

Submit your manuscripts at

http://www.hindawi.com
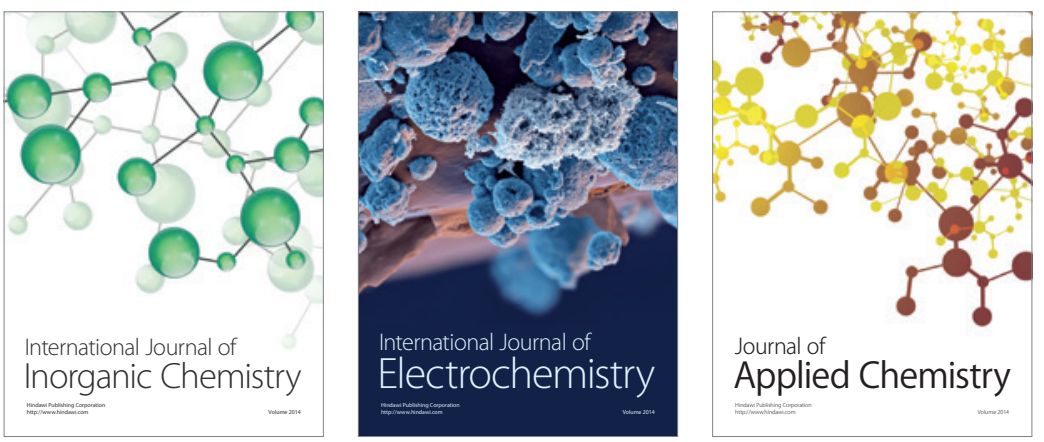

Journal of

Applied Chemistry
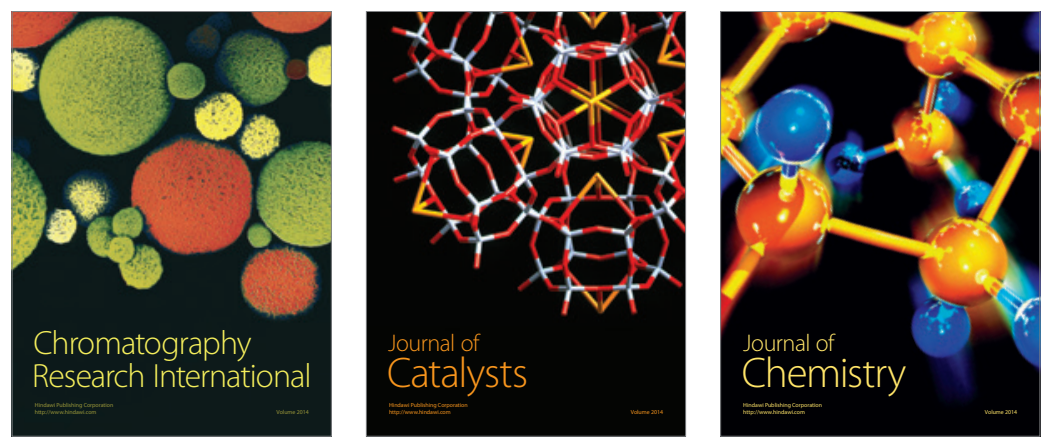
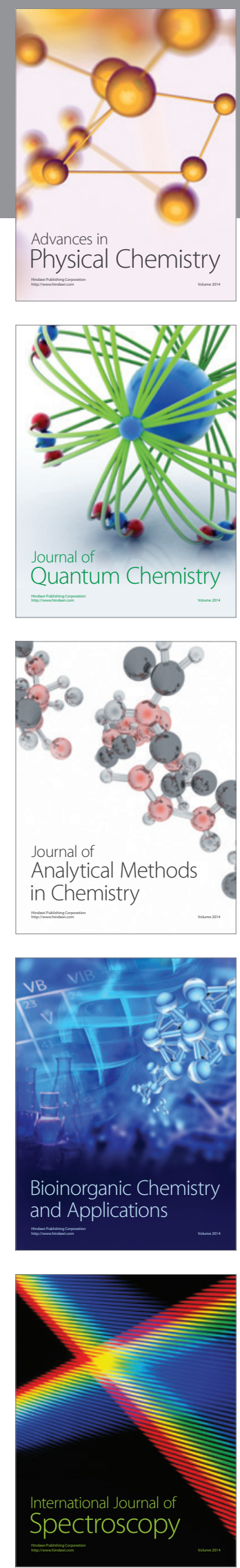